\title{
Г.Б. Хабижанова
}

Казахский национальный университет им. аль-Фараби, Казахстан, г. Алматы, e-mail: gulnara02011966@mail.ru

\section{ФЕНОМЕН ЦВЕТА В ЭТНИЧЕСКОЙ ИСТОРИИ КОЧЕВЫХ НАРОАОВ ЦЕНТРААЬНОЙ АЗИИ}

\begin{abstract}
Работа посвящена исследованию проблемы концепции цвета в этнической истории кочевников. Цель данной статьи - изучение вопроса семантики цветового обозначения в этнической структуре тюркских народов в историко-этимологическом, этнокультурном аспектах. Значимость проблемы обусловлена неразрешенностью трактовки коннотации цвета, его генезиса в названии этнонимов, необходимостью систематизации имеющихся знаний, а также комплексного подхода в исслеАовании сюжетов, касающихся формирования культурной идентичности народов, относящихся к кочевому миру. Поставленная тематика предполагает решение таких задач, как определение проблематики вопроса в контексте изученности цветообозначающей лексики в культурной традиции, выявление семиотического подхода в анализе концепта цвета, обоснование перспектив потенциала цветовой атрибуции в исследовании проблем этнической истории кочевников. Теоретическим посылом изучения вопроса стала мысль о том, что специфика колористического восприятия вк^ючена в систему мировоззрения, она присутствует в виде символов и знаков, передающих и раскрывающих семиотическую сферу этнокультурного сознания. В исследовании прослежена традиция исторического анализа цветообозначения племен и родов по кАассическим научным трудам в области тюркской истории, фольклористики и языкознания. Источниковой базой послужили письменные памятники, Аанные топонимии и устной историологии. Основными методами исследования выступили: сравнительноисторический, семиотический, семантический анализы. Специфика колористического восприятия вк^ючена в систему мировоззрения, она присутствует в виде символов и знаков, передающих и раскрывающих семиотическую сферу этнокультурного сознания. В результате проведенного исследования слелан вывод о древних истоках феномена цвета, существовании архетипов цветовых образов, восходящих к мифологии тюркских народов. Цветовая атрибуция в этнонимике кочевников имеет широкий спектр обозначения: от прямого до символического. Семантика цветообозначения зависит от исторического контекста применения, специфики сложившейся в народе культуры его употребления, исторических условий формирования родоплеменного состава.
\end{abstract}

Ключевые слова: цветообозначение, символика, этноним, культура, белый, черный, желтый, пестрый.

\author{
G.B. Khabizhanova \\ Al-Farabi Kazakh National University, Kazakhstan, Almaty, \\ e-mail: gulnara02011966@mail.ru

\section{The color phenomenon in the ethnic history} \\ of the Central Asian nomads
}

The article is devoted to the study of the color concept problem in the ethnic history of nomads. The purpose of this article is to study the issue of color designation semantics in the ethnic structure of the Turks in the historical, etymological, ethnocultural aspects. The significance of the problem is due to the unresolved interpretation of the connotation of color, its genesis in the names of ethnonyms, the need to systematize existing knowledge, as well as an integrated approach to the study of subjects related to the formation of the cultural identity that belong to nomadic world population. The topic assumes the solution of such problems as defining the problematics in the context of the study of color-denoting vocabulary in the cultural tradition, identifying a semiotic approach in the analysis of the color concept, substantiating the prospects for the potential of color attribution in the study of the ethnic history problems of nomads. The theoretical premise of studying the issue was the idea that the specificity of coloristic perception is included in the worldview system, it is present in the form of symbols and signs that convey and reveal the semiotic sphere of ethnocultural consciousness. The study traces the tradition of the historical analysis of the color designation of tribes and clans based on classical scientific works 
in the field of Turkic history, folklore and linguistics. The source base was written records, toponymy data and oral historiology. The main research methods were: comparative historical, semiotic, semantic analysis. The specificity of coloristic perception is included in the worldview system, it is present in the form of symbols and signs that convey and reveal the semiotic sphere of ethnocultural consciousness. As a result of the study, a conclusion was made about the ancient origins of the phenomenon of color, the existence of archetypes of color images dating back to the mythology of the Turks. Color attribution in the ethnonymy of nomads has a wide range of designations: from direct to symbolic. The color designation semantics depends on the historical context of application, the specifics of the culture of its use by the people, the historical conditions for the formation of the tribal composition.

Key words: color designation, symbolism, ethnonym, culture, white, black, yellow, variegated.

\author{
Г.Б. Хабижанова \\ Ә^-Фараби атындағы Қазақ ұлттық университеті, Қазақстан, Алматы қ. \\ e-mail: gulnara02011966@mail.ru

\section{Орталық Азия көшпелі халықтарының} \\ этникалық тарихындағы түс феномені
}

\begin{abstract}
Жұмыс көшпелілердің этникалық тарихындағы түс концепциясы проблемасын зерттеуге арналған. Бұл мақаланың мақсаты - түркі халықтарының этникалық құрылымындағы түстерді белгілеу семантикасы мәселесін тарихи-этимологиялық, этномәдени аспектілерде зерттеу. Мәселенің маңыздылығы этнонимдер атауындағы түс коннотациясын, оның генезисін түсіндірудің шешіммеуімен, қолда бар білімді жүйелеу қажеттілігімен, сондай-ақ көшпелі әлемге жататын халықтардың мәдени сәйкестігін қалыптастыруға қатысты сюжеттерді зерттеудегі кешенді тәсілмен байланысты. Қарастырылып отырған тақырып мәдени дәстүрдегі түстерді білдіретін лексиканы зерделеу контексінде мәселенің проблематикасын айқындау, түс тұжырымдамасын талдауда семиотикалық тәсілді анықтау, көшпенділердің этникалық тарихы проблемаларын зерттеуде түс атрибуциясы әлеуетінің перспективаларын негіздеу сияқты міндеттерді шешуді көздейді. Мәселені зерттеудің теориялық негізі колористикалық қабылдаудың ерекшелігі Аүниетаным жүйесімен байланыстылығында және этномәдени сананың семиотикалық сферасын көрсететін және ашатын белгілер мен символдар түрінде болады деген идеяда жатыр.

Зерттеуле түркі тарихы, фольклор және мингвистика саласындағы классикалық ғылыми еңбектердегі тайпалар мен рулардың түстерді белгілеу маңызына тарихи талдау жасау дәстүрі негізге алынды.

Аеректік негізі жазба ескерткіштері, топонимия және ауызша тарихнамалық деректері болды. Зерттеудің негізгі әдістері: салыстырмалы-тарихи, семиотикалық, семантикалық, талдау. Колористикалық қабылдаудың ерекшелігі дүниетаным жүйесіне негізделген, ол этномәдени сананың семиотикалық саласын жеткізетін және ашатын белгілер мен символдар түрінде болады. Жүргізілген зерттеулер нәтижесінде түс феноменінің ертеден бастау алуы, түркі халықтарының мифологиясынан жалғасатын түс бейнелерінің архетиптерінің болуы туралы қорытынды жасалды. Көшпелілер этнонимикасындағы түстердің атрибуциясы кең ауқымды белгілерге ие: тікелейлен символдыққа дейін. Түсті белгілеу семантикасы қолданудың тарихи контексіне, оны қолдану мәдениетінің ерекшелігіне, ру-тайпалық құрамның қалыптасуының тарихи жағдайларына байланысты.
\end{abstract}

Түйін сөздер: түсті белгілеу, символика, этноним, мәдениет, ақ, қара, сары, түрлі-түсті.

\section{Введение}

Концепция цвета и цветовой символизм как одна из интересных проблем в изучении этнической истории и культуры народа давно привлекали внимание исследователей. Цветовые обозначения в качестве знаков принадлежности к определенной культуре сопровождают жизнь человека с момента его появления до ухода. Известно, что с древности проведение обряда перехода ребенка из периода детства во взрослую жизнь, введение во власть, погребение человека проходило в установленных обществом кано- нах и требовало соблюдения ряда ритуалов. И цвет играл важную роль, так как он нес соответствующую семантическую нагрузку и отражал символику культуры того или иного общества. Исследование происхождения и развития цветовых предпочтений у разных народов позволяет погрузиться в сложный мир явлений культуры и интерпретировать различные аспекты, связанные, например, с передачей посредством цвета концепций мировидения, мифологические традиции, фольклорную символику, вопросы этнической истории. Большое внимание изучению цветовых коннотаций традиционно уделяет об- 
ласть языкознания, которая определяет их значение в формировании этноязыковой картины мира. При этом исследователи-лингвисты подчеркивают, что таксономия цветообозначений в каждом языке разная и имеет свои архетипические характеристики. В лингвистике, изучающей цветовые феномены в культуре разных народов, выделяются понятия этноприоритетных и этнорелевантных цветов. Сложение в каждом языке цветового восприятия окружающей действительности отражает особенности исторических и географических условий формирования культуры. Специфика колористического восприятия включена в систему мировоззрения, она присутствует в виде символов и знаков, передающих и раскрывающих семиотическую сферу этнокультурного сознания. Как полагают исследователи «языка цвета», он появился в качестве элемента знаковой системы раньше вербального языка (Серов, 2004). При этом, если рассматривать язык как систему, состоящую из собственно языка и способов его формализации, то цветовой контекст языка выступает, в свою очередь, как метаязык для понимания специфической формы отражения явлений культуры. Таким образом, цвет предстает как инструмент для создания определенных образов-концептов и несет в себе совершенно определенный смысловой заряд. Семантика цвета и его влияния рассматривались в качестве научной проблемы, как известно, и в средневековой мусульманской теоретической мысли. Согласно средневековым концепциям, цвет воспринимался как материальное воплощение духовных элементов света и тьмы. Необходимо отметить, что исследователи, изучавшие истоки цветовых представлений, пришли к выводу о существовании так называемых «цветовых универсалий» у разных народов, что не исключает и наличия особенностей, так как «чувство цвета в культуре столь же исторично, как и зрительное восприятие в целом». Известно также, что один и тот же цвет в культуре разных народов может иметь противоположное значение. Несмотря на существующий в научной литературе определенный задел исследований по тематике цвета как компонента знаковой семиотической системы, вопрос использования и трактовки цветообозначений продолжает изучаться в разных областях гуманитарного знания (Ю.М. Лотман, С.Э. Поляков и др.).

Памятники письменности, материальной культуры, устного народного творчества тюркских народов содержат богатый материал о цветовом обозначении племен и родов. Для изучения истории кочевников семантика цвета в названии этнонимов и топонимов позволяет решить некоторые вопросы, касающиеся их происхождения, географии расселения, космологические представления, в отдельных случаях определения иерархии родоплеменного устройства и военнополитической организации, а также извлечения ценных сведений по истории хозяйства и быта кочевого общества. Истоки феномена цвета в культуре народа восходят к мифологии, в которой следует искать возникновение архетипов цветовых образов. Эти аспекты взаимосвязаны также и с изучением генезиса символики и знаков в этнической культуре кочевого мира, что, в свою очередь, определяет значение исследований, связанных с вопросами идентификации этнических общностей.

\section{Материалы и методы}

Теоретическим посылом изучения вопроса стала мысль о том, что специфика колористического восприятия включена в систему мировоззрения, она присутствует в виде символов и знаков, передающих и раскрывающих семиотическую сферу этнокультурного сознания. В исследовании прослежена традиция исторического анализа цветообозначения племен и родов по классическим научным трудам в области тюркской истории, фольклористики и языкознания. Источниковой базой послужили письменные памятники, данные топонимии и устной историологии. Основными методами исследования выступили: сравнительно-исторический, семиотический, семантический анализы.

\section{Результаты и обсуждение}

Согласно одной из ранних классических научных гипотез о возникновении универсальных цветовых номинаций в языке, базовыми являются белый, черный и красный цвета (Berlin, Kay, 1969). Именно эти цвета наиболее часто встречаются в этнонимике тюркских народов. Иногда красный цвет заменяется желтым по частоте упоминаний письменными источниками.

Известно, что тюркские народы использовали в соответствии с принятой ими системой географического разделения пространства на четыре части цветовые обозначения: восток голубой/зеленый, запад - белый, север - черный, юг - красный. Стороны света, а также принятое их цветовое обозначение определялись относительно центра. Пять цветов - белый, 
черный, красный, зеленый и желтый считались у тюрков самыми употребляемыми в повседневной жизни и использовались для обозначения различных предметов и явлений, напротив, цвета голубой, пестрый, серый (боз и кыр) были предназначены для номинации определенного круга вещей.

Что касается исследований семантики наиболее употребляемых цветов в истории и культуре тюркских народов, то помимо географических обозначений черный цвет, согласно О. Прицаку, также используется в значении «истинный», например, в этнониме кара-киргизы. В то же время исследователь определил этническую атрибуцию белых калмыков, как тюрков, а точнее телеутов, в отличие от упоминаемых в источниках черных калмыков. Но цвета «белый» и «черный» могут употребляться и в смысле знака равенства, в значении «один» и «другой», как в одной тюркской сказке про Ак-хана и Кара-хана (Gaben, 1962: 112). Также в смысле «настоящий» предлагал рассматривать употребление арабским географом аль-Идриси название Черная Кумания и И.Г. Добродомов. В качестве примера использования переносного значения цветовых обозначений $а к$ и кара приводятся им упоминаемые в русских летописях племена кубанских (черные) и волжских (серебряные=белые) булгар. Название Белая Кумания отождествляется исследователем как место, относящееся, по его мнению, к западным половцам, потомкам известного племени шары (сары=ак).

При существующем универсализме подходов в толковании «цветовых» этнонимов немалую роль необходимо отводить и народной этимологии. О нецветовой сущности хроматизмов в топонимике, которая относится и к области этнонимии, писали в свое время лингвисты, когда давалось объяснение часто встречаемому, например, в казахском языке гидрониму карасу, в значении «простой», «обыкновенный» (древнетюркская форма термина «кара» - «суша», «земля») и в переводе употребляемый как «чистая, прозрачная вода». Также и в отношении гидронима аксу, когда значение цвета «ак» трактуется в значении «обилие», в данном случае «текущая вода». В этнонимике казахских племен названия с обозначением «кара» встречаются часто. Так, в состав объединения Алимулы Младшего жуза входили племена карасакал, каракесек, торткара, из которых последние, в соответствии с географическим определением цвета, располагались севернее остальных племен Алимулы. В то же время, в современном казахском языке геогра- фическое направление цвета «кара» обозначает «запад» (Койчубаев, 1974: 8).

Отмечая большой объем значений термина «кара», обращает на себя внимание одно из них, используемых в семантике этнонимов в смысле «большой, могучий» (Кононов, 1978:162). Например, в этом значении, вероятно, используется название башкирского племени кара-табын, который по гипотезе происходит от элиты енисейских кыргызов (А.С. Сальманов). В некоторых сохранившихся преданиях упоминаются указания на цветовое обозначение племен ввиду их соответствующего происхождения, как например, о племени керей, согласно легенде о котором предками его были девять черноватых братьев (Аристов, 1897: 79). Н.А. Аристов, рассуждая о цветовых обозначениях «кара» и «сары» у раннесредневековых тюргешей, высказал свое мнение, что эпитет «черный» в отношении народностей и племен означает младшую, подчиненную часть народа или племени (пример приводится в отношении названий каракиданей, кара-китаев, каракалмаков как частей своих народов, оставшихся на прежних местах обитания, т.е. как оторвавшихся от основной народности). Согласно Н. Аристову, каратюргешами, вероятно, были подчиненные желтым тюргешам (как царскому роду, аристократическому) роды дулатов и кыргызов (борьба между сары и каратюргешами разгорелась в конце правления каратюргешского хана Сулу) (Аристов, 1897: 28-29). Также и в составе казахского племени керей имеющийся род каракерей Н. Аристов считает младшим (ввиду другого происхождения), т.е. зависимым от кереев родом (Аристов, 1897: 84). И все же в большинстве случаев в названиях этнонимов с присутствием цвета, как считал А.Кононов, цветовое обозначение играло роль детерминатива, а именно обозначало «исторически исходное географическое положение их носителей по отношению к их главному роду, носящему то же название» (Кононов, 1978: 168). Отмечая сложность исследования вопроса об этимологии термина «туркмен», используемого в средневековых письменных источниках, Г. Вамбери привел в качестве примера одно из обозначений слова «кара» в значении «народ»«kara=Volk» (Vambery, 1885: 382- 391).

\section{Сары в составе этнонимов}

В отношении термина «сары» в этнонимах в научной литературе также существует достаточно много толкований. В казахском языке «нецветовое» применение слова «сары» может исполь- 
зоваться в значении «верховный, главный», а слова «кызыл» - «мелкий» (Койчубаев, 1974: 9). В этнонимике тюркских народов присутствует большое количество наименований с цветовым обозначением сары (сарыусунь, сарыбагыш, сарыюгур, сарыхлар, алтысары и др.). Н. Аристов указывал на существование рода сары-уйсунь в составе Старшего жуза казахов, который, как он считал, происходил от древних усуней, давших свое название в качестве собирательного имени всем племенам этого объединения, ввиду сохранения в нем прямых потомков древних усуней, а также наследования их земель, занимавшихся самими племенами Старшего жуза. Исследователь напоминает, что происхождение усуней, сары уйсуней восходит к смешению тюрков с динлинами, как и у родов сары и бессары соответственно в составе племен алаша и тана Младшего жуза (Аристов, 1897: 111). Обосновывая динлинские корни у средневековых племен с цветовым обозначением capbl, автор указывал и на урянхайские племена (туба, т.е. тувинцы), среди которых назывались роды сарыхлар у сагайцев (сарыг), жетысары и алтысары у кыргызов (Аристов, 1897: 74). Ч. Валиханов сообщал о том, что китайские летописи отмечали среди народов Центральной Азии шесть племен с голубыми глазами и рыжим цветом волос, к числу которых принадлежали усуни. Что касается географического определения термина capbl в этнонимах, как уже отмечалось, он идентифицируется с понятием «центр» или, как и цвет ак обозначает направление «запад». Так, соответственно, этноним сарыгюгуры, располагавшиеся к северо-западу от Китая, имел перевод «западные уйгуры» (Кононов, 1978: 176). Отождествление А.Н. Кононовым цвета $а к$ и $\mathrm{capb}$ основывается на анализе нескольких терминов с обозначением сары, которые, как например, название хазарской крепости Саркел, средневековый автор Константин Багрянородный перевел как «Белый дом», а русские летописи «Белая Вежа» (Кононов, 1978: 175). В то же время, Е. Койчубаев приводит противоположную версию перевода ак в значении «восток» (Койчубаев, 1974: 9).

Широко известна предложенная в свое время гипотеза этимологии упоминаемого в русских летописях названия половцы, связанная с описанием внешности этого племенного объединения кочевников. Цвет куба в древнетюркском языке означал «между красным и желтым», из которого производили термин «куман» (И.Г. Добродомов). То есть разные наименования половцев, с которыми связывают такие племена как куманы, кыпчаки, хардеш, сорочины, куны, куманды, являются калькой перевода «желтый» или «бледный», ввиду их внешнего вида (светловолосые и светлокожие) или особенностей места их проживания (желтых степей). Что касается этнической атрибуции средневековых племен, упоминавшихся в разных письменных источниках, связанных с цветовым обозначением «желтый», то научная дискуссия имеет свое продолжение. Часто перевод цвета сары звучит как «рыжий» или «красноватый». По мнению С. Кляшторного, термин сары чаще был в использовании у кыпчаков, в то время как у огузов преимущественно употреблялось слово кызыл. В отношении цветового обозначения у племен автор склонялся к мысли, что таким образом была организована структурная система союза племен. Продолжая свою мысль о цветовом маркировании у племен, автор указывал на обязательное изначальное возникновение парных цветов в названии племен (как например, ак кете и кара кете, ак коюнлу и каракоюнлу, конырборик и кызылборик, сарытюргеш и каратюргеш и т.д.). Но как только цветовое обозначение превращается в течение времени в устойчивый этноним, это свидетельствует о распаде племенного объединения и утере атрибутивной семантики цвета.

\section{«Кызыл» в тюркской этнонимии}

Этимологию красного цвета, также считающегося одним из главных цветов, сформировавшихся в языке и используемых в обозначении племен, связывают, как указывалось, символически с южной стороной света. Известна трактовка этнонима «кыргыз» с маркировкой красного цвета: кыргуз (красные огузы), кыр (кызыл) - в значении «краснощекие», кыргу-аз - красные азы (Н.А. Баскаков, А.Н. Кононов, К.И. Петров). Во многом этот взгляд подкрепляется фольклорной версией происхождения кыргызов от т.н. «красной собаки» - кызыл тайган (Ч.Ч. Валиханов). К.И. Петров считал, цвет «кызыл-красный» употреблялся в этнониме кыргыз в качестве топоэтнонима (Петров, 1964: 81).

В составе племен Младшего жуза казахов есть племя кызылкурт. Впервые об этом племени упоминается у А. Левшина. О племени кзылкурт Байулы сообщается, что ввиду разнообразия тамг этого племени происхождение его носит, возможно, смешанный характер. Исторические и этнические взаимосвязи племен иногда устанавливаются путем сравнения родовых тамг, а также наличием подобных названий в 
подразделениях родов, входящих в другие племена. Так, в составе казахского племени тама из Младшего жуза имеется подрод кзылкурт. Подобный же подрод имеется в составе племени ысты из Старшего жуза. Здесь даже отмечается аналогичность тамг. По И. Казанцеву у племени тама Младшего жуза в составе есть род кизилкурт. Н. Аристов также упоминает, что в Букеевской орде в числе 16 племен Младшего жуза, кочевавших с ханом Букеем, значатся кизилкурт и тама (Аристов, 1897: с.111). Некоторые тамги племени кзылкурт позволяют проследить взаимосвязь в основном с племенами Младшего жуза: байбакты и маскар. Интересно отметить один факт: казахское племя тама, как известно, принадлежит казахскому племенному объединению Жетыру, в племенном же составе киргизов есть племя саруу, в одном из подразделений которого, а именно жетауруу также есть род кызыл-курт. Одна из тамг племени кзылкурт также имеет форму косеу, что является косвенным доказательством этнического родства кзылкуртов с кипчаками. Следовательно, можно предположить общность их исторических судеб, начиная с XI в., когда в составе кипчакского объединения находилось большинство будущих казахских племен Младшего жуза. Можно отметить также, что имеющийся в составе казахского племени кзылкурт род суба (саба) имеет предположительно тюркское происхождение, так как в переводе с тюркского «субэ, сюйбу» означает область, край (Кузеев, 1974: 309). Дословный перевод этнонима кызылкурт означает «красный волк», однако есть и иное значение слова «курт» (в казахском языке - «червь»). По этому поводу высказана интересная гипотеза о мифологическом перевоплощении тесно связанных между собой тотемного образа змеи или дракона в образ волка.

\section{Цветовое обозначение «ала» и этноисто- рические параллели}

Еще одним важным цветом, характеризующим «цветовую» этнонимику тюркского мира, является обозначение «пестрый». В мифологии тюркских народов, как известно, пространственно-хроматический образ среднего мира обозначается пестрым цветом. Достаточно часто семантику цветового обозначения племен выводят из хозяйственных реалий, их образа жизни. Так, средневековое название народа «пеголошадников» объясняют существовавшим культом лошади. Общеизвестно значение сакральных жи- вотных в жизни кочевых народов. Этот фактор получил свое отражение и в наименовании этнонимов. В истории тюркских народов существует множество легенд, связывающих их происхождение с образами ставших позднее тотемами племенных животных (волк, бык, олень, медведь и др.). В этой связи особая роль отводится у кочевников образу коня. Часто в этнонимах исследователи видели отражение масти лошади, которая, возможно, считалась у данного племени излюбленной (конырат, боролдой (у монголов), торайгыр). Название племени, как отражение образа жизни у кочевников, было подмечено В.А. Гордлевским в термине «топчак атлык» из «Бабур-наме» в значении «упитанная, красивая лошадь» (Гордлевский, 1947: 326).

В традиционной культуре народа саха (самоназвание якутов) известно божество коневодства Джесегей (Дьөһөгөй). В настоящее время культ лошади сохранился в празднике ысыах (праздник кумыса), проводящемся летом и сопровождающемся обрядами и ритуалами в честь айыы (божества) Дьөһөгөй. При этом особыми почестями пользуются лошади пегой масти - ала ат. Отмечается, что для якутской мифологии в целом характерно большое количество слов с термином ала: «Ала Буурай - владычица Нижнего мира, Аан Алахчын - изначальная матьземля, алаатыыр - восклицание, герои олонхо Ала Туйгун или Ала Хара, Ала Хотогой, Ала Тамына». При этом значение слова «ала» амбивалентно, оно также может быть включено и в имена демонических персонажей, например абаасы (по-казахски - албасты) «Ала Могой, Ала Марайдаан, Ала Дыбын, Ала Джаатара Тойон» (В.В. Ушницкий).

Согласно приводимой И. Казанцевым легенде о происхождении казахских племен Младшего Жуза, «... во владениях хана Алача или Алачена стали рождаться «пегие или чубарые люди, называемые ченчак» (должно быть от оспы - догадка Казанцева) - рябые»: Хан приказал лишить жизни матерей, у которых будут такие дети, но и у любимой его жены родился пегий сын; хан даровал ей жизнь, но велел выпроводить вместе с сыном в степь, «дав ему в утешение кирк-гыз, т.е. сорок дев», от которых произошло потомство и народ киргизы» (Аристов, 1897: 106-107). Эту легенду Н. Аристов связывает с народом динлин, ала, которые обитали в стране Алакчин, «где по тюркской пословице все лошади пегие, а очаги - золотые. Эта страна располагалась в устье Ангара-Мурана, т.е. Енисея, как сообщал 
Абулгазы-бахадур-хан» (Аристов, 1897: 107). И далее, пишет Н.А. Аристов, отсюда следует, что племена Младшего Жуза произошли в результате смешения тюрков с западными динлинами и угро-финнами.

Китайский источник «Обозрение Танской династии» называет племя гэ-ло-чжи (э-ло-чжи) и племя «пегие лошади» (бома). Названия этих племен считаются китайской транскрипцией тюркского слова «ала». Часть этого племени входила в состав басмылов, киргутов, которые были завоеваны западнотюркскими каганами в VII в. Ю. Зуев отмечал, что племя э-ло-чжи восходит к алачин или алчин, как известно, так называются собирательно казахские племена Младшего жуза. О месторасположении пеголошадных племен Ю.Зуев указывает на истоки Ангары и район восточного побережья озера Байкал, называемого в китайских хрониках «Бэй-хай» - «Северное море». Китайские источники определяют место обитания алачинов к северу от тюрков, рядом с киргутами у моря. У А. Левшина сохранилось записанное им предание, в котором говорилось о том, что некогда казахи составляли одно целое с алатами или сибирскими татарами. Однако они отделились от них вследствие внутренних разногласий (Левшин, 1832: 27). Что касается описания хозяйства пеголошадных, то «Таншу» сообщает следующее: «Находятся на севере от ту-цюэ; отстоят от столицы на 14000 ли. Следуют за травой и водой (т.е. кочуют), но в основном живут в горах. Строевого войска 30000 человек. Там всегда снег, и деревья не опадают. Пашут поля лошадьми, лошади цветом все пеги, поэтому и государству дано такое же название. Живут на севере близ моря. Хотя имеют лошадей, но верхом на них не ездят, а используют их молоко для пищи. Часто воюют с цзе-гу» (Зуев, 1960: 124).

Абулгази сообщает следующие сведения о племени пегих лошадей: «Множество их племен кочевало по берегам Ангара-Мурэни, которая, пройдя по востоку страны киргизов и приняв дань множества речек, увеличивающих ее воды, впадает в море. В устье этой реки, на берегу моря, есть большой город, вокруг которого находится поблизости множество селений, где располагались в большом числе кочевые племена. Их лошади были велики... Все они были пеги по цвету, других не имелось. Недалеко от этого города, называемого Алакчин, имелся серебряный источник, поэтому все котлы, блюда и вазы... были из серебра. Это та страна, которую узбе- ки имеют в виду, когда говорят: «Есть страна, где все лошади пеги, а очаги из золота» (АбульГази-Бахадур-хан, 1996: 34). Эти сюжеты стали основой для обоснования гипотезы о происхождении этнонимов от топонимии. Так, при анализе этнонимов алагчын, алаты, которые, как считалось, были произведены от термина ал(a), образовали тем самым целую группу этнотопонимов, имеющих народный характер этимологии (Петров, 1964: 87).

Упоминание А. Левшиным предания о совместном пребывании казахов с алатами и сибирскими татарами напоминает также о термине «Алаш» или алаша (казахский род в составе Младшего жуза), что, как известно, боевым ураном средневековых казахов и отождествляется часто с самим этнонимом «Казах». Кроме того, вышеуказанные сведения об алатах, элементы которых вошли в состав басмылов и кыргызов, а племя гэлочжи часто сопоставляют с карлуками, позволяют провести некоторые этнические параллели в истории формирования якутского и казахского народов (В.В. Ушницкий). Известно, что согласно фольклорным данным, предком якутского народа считается Эллэй боотур, у которого был сын Болотой Оххон. Известна также версия взаимосвязи казахского племени аргын со средневековыми басмылами через их обозначение «смесь» и с карлуками. Также и об одном из карлукских племен известно название булат (также алка-булак). В таком случае возникает гипотеза об этнической взаимосвязи казахов и якутов. Разбирая казахское шежире Среднего жуза, В. Востров и М. Муканов пришли к выводу, что родоначальники Среднего жуза Аргын и Булат есть не что иное, как этническое воплощение легендарного предка. Обоснованием такого вывода стали ссылки на отождествление имен предков с названиями казахских жузов. Так, если родоначальником Старшего жуза называется Уйсун и соответственно племена этого жуза именуются уйсунскими, Младший жуз имеет название алчинского по аналогии со Старшим жузом, а Средний жуз по преданиям имеет родоначальником то Болата-ходжу, то Аргына, следовательно, по мнению выше названных исследователей, «Булат и Аргын - этническое воплощение легендарного образа». Все это позволило этнографам предположить существовавшую в древности связь имени родоначальника Среднего жуза Болата с названием западной части карлукского племенного объединения булат или булук (Худуд ал-алам, М. Кашгари). Это племя в VIII-IX вв. 
обитало в долине р. Или. Что же касается взаимосвязи карлуков и басмылов, то известно, что они состояли вместе с 9 племенами хойху в политическом союзе и получили название «народ одиннадцати племен». При этом, как указывали китайские источники, эти «посторонние поколения - басими и гэлолу» (т.е. карлуки) всегда в военных походах шли впереди» (Бичурин, 1998: 315). Необходимо отметить и тот факт, что происхождение якутского народа, связываемое большей частью с тюркоязычными племенами и курумчинской раннесредневековой культурой, а также племенами западных тюрков - тюргешами и на позднем этапе своего формирования сопряжено с наличием кипчакского пласта, представленного южносибирской кыпчакской группой, а именно кангаласцами (А.П. Окладников, А.И. Гоголев, Ф.Ф. Васильев). Взаимосвязи с кыпчаками прослеживаются и в материальной культуре народа саха. В истории исследования проблемы происхождения якутов имеются разные гипотезы, связывающие этногенез со средневековыми кереитами, джалаирами, канглы, а также с территорией Арала, которая согласно анализу эпоса олонхо, могла быть прародиной предков саха. Конечно, речь идет не о прямом, а опосредованном участии племен тюркского периода в качестве субстрата в этногенезе этого народа.

\section{Көк}

Голубой цвет (кок), который относится в тюркской системе цвета к разряду периферийных, тем не менее, также присутствует в их этнической истории, а в системе географических координат определял восточное направление. Соответственно, противоположное, т.е. западное направление определялось белым цветом, что и положило начало известной дискуссии о наследниках территории улуса Джучи, делившегося на правое и левое крылья. Степная историология сохранила древние свидетельства о разделении Чингизханом земель между потомками, в соответствии с чем эти территории по цвету возведенных юрт получили название Белой и Синей орд. Вместе с географическим определением их местоположения обозначение цвета носило указание о социальной стратификации владельца тех или иных земель. Так, иерархия цветов свидетельствовала о том, что белый и золотой цветы символизировали старшинство, а синий - подчиненность (В.П. Юдин). О разграничении голубого и синего цветов существует мнение, что первоначально цвет мог означать определенный спектр, чем объясняется, напри- мер, нечеткая разделенность в языке многих тюркских народов голубого и зеленого (кок) колора (Laude-Cirtautas, 1961: 80). Таким образом, разделение голубого и синего, возможно, относится к более позднему времени. При этом употребление цветового обозначения могло иметь специфический характер. Так, наименование масти белой лошади, ввиду редко встречаемого в «чистом» виде, могло передаваться через цветовое обозначение кок или боз, также и в значении серый=голубой (кок бори). О синем цвете, как символическом колоре в искусстве у тюрков писал В.А. Гордлевский, приводя примеры о том, как обозначали половцы реку Дон, и общеизвестном термине «Синяя орда» (Гордлевский, 1947: 327). В отношении термина «голубые тюрки», интерпретируемого чаще всего как тюрки в значении династия Ашина, высказана и другая точка зрения, восходящая к толкованию термина кӧк в смысле «зелень», «корень» и получившая формулировку «коренные, или простые тюрки» (Тишин, 2014: 78-83).

\section{Заключение}

Таким образом, цветовое обозначение в названии племен является одной из проблем, находящихся в плоскости исследования разных областей научного знания. В теоретическом плане цветовая коннотация выступает в качестве маркера, отражающего символику культуры, некий ее концепт, раскрывающий структуру мировидения, обычаи и традиции, особенности адаптации этноса к окружающей действительности. Попытка обоснования семантики цвета в культуре того или иного народа уходит в древность. Тем не менее, в этом вопросе до настоящего времени отсутствует единство мнений, так как интерпретация цвета, выступающего как элемент знаковой системы, осложняется многозначностью его лексического, грамматического текстологического и, наконец, абстрактного содержания. При непосредственной трактовке «цветовых» этнонимов, например, исходящих из характеристики описываемых средневековыми авторами внешних данных представителей того или иного племени, по-прежнему не исключаются и сложности палеографического анализа самого источника. В этом отношении в дальнейшем исследовании представляется перспективным изучение имеющихся в источниках этноцветовых наименований родоплеменной структуры социума в тесной взаимосвязи с 
анализом материалов фольклора, топонимики, мифологических образов, а также реконструкцией этноисторических контактов, позволяющих определить культурные взаимодействия народов на разных этапах их формирования.
Исследование выполнено в рамках научного проекта грантового финансирования МОН РК АР09261323 «Сакральность символов и атрибутов в этнической культуре кочевников Центральной Азии».

\section{Литература}

Абуль-Гази-Бахадур-хан. (1996). Родословное древо тюрков. Москва-Ташкент-Бишкек: Туркестан. 544 с.

Аристов Н.А. (1897). Заметки об этническом составе тюркских племен и народностей и сведения об их численности. Санкт-Петербург: Типография С.Н.Худекова. 182 с. (Отт. из: Живая старина. 1896. Вып. 3-4).

Berlin B., Kay P. (1969). Basic color terms: Their universality an evolution. Berkeley \& Los Angeles: University of California Press. 212 p.

Бичурин Н.Я. (1998). Собрание сведений о народах, обитавших в Средней Азии в древние времена. Алматы: ТОО «Жалын баспасы». Т. 1.390 с.

Vambery H. (1885). Das Türkenvolk in seinen ethnologischen und ethnographischen Beziehungen. Leipzig: F.A.Brockhaus. $638 \mathrm{~s}$.

Gaben A.von. (1962). Vom Sinn symbolischer Farbenbezeichnung. Acta Orientalia. T.XV. Budapest. S.111-117.

Гордлевский В.А. (1947). Что такое «босый волк»? (К толкованию «Слова о полку Игореве»). Известия АН СССР. Т.VI. Вып.4. С. 317- 337.

Зуев Ю.А. (1960). Тамги лошадей из вассальных княжеств. Новые материалы по древней и средневековой истории Казахстана. Алма-Ата: АН КазССР. С.93-140.

Койчубаев Е. (1974). Краткий толковый словарь топонимов Казахстана. Алма-Ата: Наука. 275 с.

Кононов А.Н. (1978). Семантика цветообозначений в тюркских языках. Тюркологический сборник. 1975. Москва: Наука, ГРВЛ. С.159-179.

Кузеев Р.Г. (1974). Происхождение башкирского народа. Москва: Наука. 576 с.

Laude-Cirtautas I. (1961). Der Gebrauch der Farbbezeichnungen in den Türkdialekten. Ural Altaische Bibliothek, X. Wiesbaden Otto Harrassowitz. $137 \mathrm{~s}$.

Левшин А.И. (1832). Описание киргиз кайсацких орд и степей. Санкт-Петербург: Тип. Карла Крайя. 264 с.

Петров К.И. (1964) К этимологии термина «кыргыз». Советская этнография. Москва: Наука. С.81-92.

Серов Н.В. (2004). Цвет культуры. Санкт-Петербург: Речь. 672 с.

Тишин В.В. (2014). К интерпретации сочетания kök türk. Проблемы востоковедения. №1(63). Уфа: Гилем. С.78-83.

\section{References}

Abul'-Gazi-Bakhadur-khan. (1996). Rodoslovnoye drevo tyurkov [Family tree of the Turks]. Moskva-Tashkent-Bishkek: Turkestan. 544 p.

Aristov N.A. (1897). Zametki ob etnicheskom sostave tyurkskikh plemen i narodnostey i svedeniya ob ikh chislennosti [Notes on the ethnic composition of the Turkic tribes and peoples and information on their numbers]. Sankt-Peterburg: Tipografiya S.N. Khudekova. 182 p. (Ott. iz: Zhivaya starina. 1896. Vyp. 3-4).

Berlin B., Kay P. (1969). Basic color terms: Their universality an evolution. Berkeley \& Los Angeles: University of California Press. 212 p.

Bichurin N.YA. (1998). Sobraniye svedeniy o narodakh, obitavshikh v Sredney Azii v drevniye vremena [Collection of information about the peoples who lived in Central Asia in ancient times]. Almaty: TOO «Zhalyn baspasy». T. 1. 390 p.

Vambery H. (1885). Das Türkenvolk in seinen ethnologischen und ethnographischen Beziehungen. Leipzig: F.A.Brockhaus. $638 \mathrm{~s}$.

Gaben A.von. (1962). Vom Sinn symbolischer Farbenbezeichnung. Acta Orientalia. T.XV. Budapest. S.111-117.

Gordlevskiy V.A. (1947). Chto takoye «bosyy volk»? (K tolkovaniyu «Slova o polku Igoreve») [What is a "bosyy wolf”? (To the interpretation of "The Lay of Igor's Campaign")]. Izvestiya AN SSSR. T.VI. Vyp.4. P. 317- 337.

Zuyev YU.A. (1960). Tamgi loshadey iz vassal'nykh knyazhestv [Tamgas of horses from vassal principalities]. Novyye materialy po drevney i srednevekovoy istorii Kazakhstana. Alma-Ata: AN KazSSR. P. 93-140.

Koychubayev Ye. (1974). Kratkiy tolkovyy slovar' toponimov Kazakhstana [Brief explanatory dictionary of toponyms of Kazakhstan]. Alma-Ata: Nauka. 275 p. 
Kononov A.N. (1978). Semantika tsvetooboznacheniy v tyurkskikh yazykakh [Semantics of color designations in the Turkic languages]. Tyurkologicheskiy sbornik. 1975. Moskva: Nauka, GRVL. P.159-179.

Kuzeyev R.G. (1974). Proiskhozhdeniye bashkirskogo naroda [The origin of the Bashkir people]. Moskva: Nauka. 576 p.

Laude-Cirtautas I. (1961). Der Gebrauch der Farbbezeichnungen in den Türkdialekten. Ural Altaische Bibliothek, X. Wiesbaden Otto Harrassowitz. $137 \mathrm{~s}$.

Levshin A.I. (1832). Opisaniye kirgiz kaysatskikh ord i stepey [Description of the Kirghiz Kaisak hordes and steppes]. SanktPeterburg: Tip. Karla Krayya. 264 p.

Petrov K.I. (1964) K etimologii termina «kyrgyz» [On the etymology of the term „Kyrgyz“]. Sovetskaya etnografiya. Moskva: Nauka. P. 81-92.

Serov N.V. (2004). Tsvet kul'tury [The color of culture]. Sankt-Peterburg: Rech'. 672 p.

Tishin V.V. (2014). K interpretatsii sochetaniya kök türk [To the interpretation of the combination kök türk]. Problemy vostokovedeniya. №1(63). Ufa: Gilem. P. 78-83. 